\title{
In Vitro Evaluation of Apical Sealing in Root Apex Treated with Demineralization Agents and Retrofiled with Mineral Trioxide Aggregate Through Marginal Dye Leakage
}

\author{
Claudio Hideki KUBO ${ }^{1}$ \\ Ana Paula Martins GOMES ${ }^{1}$ \\ Maria Nadir Gasparoto MANCINI² \\ Departments of ${ }^{1}$ Restorative Dentistry and ${ }^{2}$ Bioscience and Oral Diagnosis, Faculty of Dentistry of São José dos Campos,
State University of São Paulo (UNESP), São José do Campos, SP, Brazil
}

The purpose of this study was to evaluate the apical seal in root apex treated with different demineralization agents and retrofilled with mineral trioxide aggregate (MTA) using marginal dye leakage. Fifty-six, human single-rooted teeth were instrumented, filled, resected and had retrofilling cavities prepared with ultrasonic tips. Demineralizing agents were applied before the apical cavities were retrofilled with Pro Root MTA. The specimens were assigned to 4 groups ( $\mathrm{n}=14)$, as follows: group 1 (no demineralizing agent); group 2 (35\% phosphoric acid, for 15 s); group 3 (17\% EDTA solution, $\mathrm{pH}$ 7, for $3 \mathrm{~min}$ ); and group 4 (24\% EDTA gel, pH 7, for 4 min). The extension of dye $\left(2 \%\right.$ rhodamine $\mathrm{B}$, at $37^{\circ} \mathrm{C}$, for $\left.24 \mathrm{~h}\right)$ penetration was measured in millimeters using a stereomicroscope. Results were statistically analyzed by ANOVA and Tukey's test at 5\% significance level. Among the experimental groups, the least extension of dye penetration was observed in group $1(1.89 \mathrm{~mm})$, followed by groups $2(2.18 \mathrm{~mm}), 4(2.54 \mathrm{~mm})$ and 3 (2.64 mm). No statistically significant differences $(\mathrm{p}<0.05)$ were found in marginal microleakage among groups 1,2 and 4 and groups 2,3 and 4 . Based on the results obtained in this study, it may be concluded that the application of demineralizing agents cannot be recommended when MTA is used in periradicular surgeries.

Key Words: Endodontics, demineralization agents, dye, microleakage, MTA.

\section{INTRODUCTION}

The use of manual, rotary and/or ultrasonic cutting instruments on root dentin surface during periradicular surgery produces smear layer, which is composed of organic and inorganic material and can contain microorganisms and its endotoxins (1). It has been reported $(1,2)$ that the application of demineralizing agents, either acids or chelating, can improve the action of root canal dressings, adhesion and penetration of retrofilling materials, and make root surface more biocompatible, optimizing periodontal healing and not interfering with apical retrofilling seal. On the other hand, smear layer removal can increase dentin permeability, facilitating bacterial penetration and reinfection of dentinal tubules if the sealing fails (1).
Different materials have been used to seal the pathways of communication between the root canal system and the oral cavity or periradicular tissues. These materials must be biocompatible and should favor regeneration of the involved tissues to their prediseased status (3). Mineral trioxide aggregate (MTA) has been developed at Loma Linda University as a promising option to seal communications between the tooth and the external surfaces (4). This material is currently marketed under the brand name Pro Root MTA(Dentsply, Tulsa, Oklahoma, USA). Several studies have shown the clinical applicability of MTA, especially in periradicular surgeries (5-10).

This in vitro study evaluated the effects of different demineralizing agents on marginal leakage on root-end fillings with Pro Root MTA. 


\section{MATERIAL AND METHODS}

Fifty-six human single-rooted teeth were used in this experiment. All teeth were extracted for periodontal reasons and the study protocol was approved by the local Ethics in Research Committee (Protocol number 051/2000 - PH/CEP). After extraction, the teeth were kept in $10 \%$ buffered formalin for 1 week and then stored in saline prior to instrumentation. The teeth were decoronated using a \#57 carbide bur (Sybron Canada, Ontario, Canada) at high-speed with water spray coolant. Average root length was $18 \mathrm{~mm}$.

After enlarging the apical foramen up to a size 20 K-file (Maillefer, Ballaigues, Switzerland), root canals were instrumented at $1 \mathrm{~mm}$ from the apex up to a size $50 \mathrm{~K}$-file (Maillefer), cleaned and shaped using standard step-back technique. Five milliliter of $1 \%$ sodium hypochlorite (Byofórmula Tecnopharma, São José dos Campos, São Paulo, Brazil) was used as irrigant at each change of file. After final irrigation, canals were dried with paper points (Diadent, Chongju City, Korea) and obturated with laterally condensed gutta-percha (Diadent) and AH Plus sealer (Dentsply De Trey GmbH, Konstanz, Germany). After removing $3 \mathrm{~mm}$ of excess filling material, the access cavities were closed with Cavit cement (ESPE, Premier Sales Corp., Norristown, PA, USA). The roots were stored in a closed glass recipient containing sterile saline and maintained in an incubator at $37 \pm 1^{\circ} \mathrm{C}$ for one week.

Apical root resections were made by removing $3 \mathrm{~mm}$ of the apex at a 90-degree angle to the long axis of the root with a water-cooled \#57 carbide bur (Sybron) at high-speed. The resected root-ends were smoothed with a double-sided carborundum disk (23.8 mm x 0.6 mm; Dentorium Export Ltd, New York, NY, USA).

A supporting matrix was developed for apical cavity preparation. This device was composed of two nylon plates with an inner channel (in each plate), which locked the roots at $45^{\circ}$ inclination and allowed standardizing the position of cavity preparation. This matrix protected the specimens from the pressure of the vice (\#3; Fort Line, São Paulo, SP, Brazil) and kept them gripped during ultrasonic preparation.

The root-end cavities were prepared using an ultrasonic unit (Jet Sonic Plus; Gnatus Equipamentos Médico-Odontológicos, Ribeirão Preto, SP, Brazil) with ultrasonic tips (S12D-90 model; Satelec, Merignac Cedex, France). A 3-mm deep class I root-end cavity was made in the resected root-end at the highest frequency setting. Cutting with the ultrasonic tips was performed using a feather-like back and forth motion with the tip enveloped in water spray.

The 56 roots were randomly assigned to 4 groups ( $\mathrm{n}=14)$ : in group 1 , no demineralizing agent was applied to the roots; in group 2, the root-end cavities and resected apical surface were etched with $35 \%$ phosphoric acid gel (Scotchbond Etching Gel; 3M/ESPE, St. Paul, MN, USA) for $15 \mathrm{~s}$; in groups 3 and 4 the demineralizing agents were $17 \%$ ethylenediaminetetraacetic acid (EDTA) aqueous solution, pH 7.0, for 3 min (Byofórmula Tecnopharma) and 24\% EDTA gel, pH 7.0, for 4 min (Farmavida, Guaratinguetá, SP, Brazil), respectively. The agents were applied passively with $1.0 \mathrm{~mL}$ syringes (SR Hospital Products, São Paulo, SP, Brazil), in a way that the root-end cavities and resected root surfaces were evenly coated. After application, the agents were aspirated and the canals were irrigated with $10 \mathrm{~mL}$ saline and dried with absorbent paper points.

The root-end cavities were retrofilled with Pro Root MTA (Dentsply), mixed according to the manufacturer's instructions. The material was condensed into the cavities using small pluggers (\#10670, SSWhite, Rio de Janeiro, RJ, Brazil). Excess material was removed with wet cotton pellets and the roots were kept in a $100 \%$ humidity environment at $37^{\circ} \mathrm{C}$ for 24 h. Each pouch of Pro Root MTA contained $1 \mathrm{~g}$ and was used to retrofill one group (14 specimens).

Twenty-four hours after retrofilling, the roots were mounted on a utility wax plate and were surfacecoated with three layers of red nail varnish (Colorama, São Paulo, SP, Brazil). The varnish was applied onto the entire root surface, except for the area corresponding to the resected apical surface, and was left drying. Afterwards, the area protected with the varnish was coated with a layer of sticky wax (Horus, Dentsply Ind. e Com. Ltda, Rio de Janeiro, RJ, Brazil) to complete sealing. Eight roots were used as positive and negative controls (two roots per group). For the specimens used as positive controls, the canals were obturated only with gutta-percha, and the demineralization agent was applied in the same way as for the corresponding experimental group, keeping root surface without any coating. For the specimens used as negative controls, the canals were obturated with gutta-percha and sealer, the demineralization agent was applied in the same way as for the corresponding experimental group and root 
surface was coated varnish and wax, as previously described.

The roots were then immersed in 2\% rhodamine B (mol wt 479; Synth, Labsynth Ltda, Diadema, SP, Brazil) aqueous solution ( $\mathrm{pH} 7.03$ ) in $0.2 \mathrm{M}$ phosphate buffer. The specimens were first submitted to lowpressure conditions (25 polHg for 90 min; Dia-Pump, Model CAL - BF1725, FANEM Ltd, São Paulo, SP, Brazil) and then kept in an environment at $37 \pm 1^{\circ} \mathrm{C}$ and $100 \%$ relative humidity for $24 \mathrm{~h}$. This methodology took in consideration the findings of a previous study (11), which reported that leakage is higher when air is removed by a vacuum pump and teeth are immersed in dye for $24 \mathrm{~h}$. In this study, the air was removed with a vacuum pump in a way that trapped air could not affect apical microleakage results.

After dye testing, the teeth were washed in running water for $5 \mathrm{~min}$ and left drying at room temperature for $24 \mathrm{~h}$. The varnish and sticky wax coatings were removed with a scalpel blade and a guide groove was prepared with a diamond disc (\#7020, KG Sorensen, Barueri, SP, Brazil) in a crown-apex direction on both buccal and lingual surfaces to nearly the depth of the canal. Roots were longitudinally split using a large spoon excavator and each half was fixed on a glass slide with epoxy resin (Ciba-Geigy, São Paulo, SP, Brazil). Linear dye penetration was measured using a stereomicroscope (Stemi 2000-C model, Carl Zeiss, Germany) with a $0.1-\mathrm{mm}$ ocular grid at X10 magnification. The extension of dye penetration between the retrofilling material and tooth structure along both coronal and apical interfaces was assessed by two experienced examiners calibrated for the technique and blinded to the groups. Eight leakage measurements were obtained for each specimen.

The highest leakage values per specimen attributed by the examiners were selected and microleakage means recorded for the experimental groups were analyzed statistically by one-way ANOVA and Tukey's test. Statistically significant differences among the groups were set at $\mathrm{p}<0.05$.

\section{RESULTS}

Total dye penetration was observed between gutta-percha and dentinal walls in the positive control samples. No dye penetration was observed in the negative control specimens. The lowest dye penetration means was observed in group $1(1.89 \pm 0.79 \mathrm{~mm})$, followed by groups 2 ( $2.18 \pm 0.37 \mathrm{~mm}), 4$ ( $2.54 \pm 0.88$ $\mathrm{mm})$ and $3(2.64 \pm 0.33 \mathrm{~mm})$. Statistical analysis by one-way analysis of variance and Tukey's test did not show significant differences $(\mathrm{p}>0.05)$ in marginal microleakage among groups 1,2 and 4 and groups 2,3 and 4. Group 3 (17\% EDTA solution, pH 7.0) had significantly higher microleakage than group 1 (no demineralizing agent) $(\mathrm{p}<0.05)$.

\section{DISCUSSION}

In this study, the smear layer of root-end cavities was removed because it can be disintegrated or dissolved by soluble products from bacterial metabolism, such as acids and enzymes (1) or saliva, thus causing gap formation between the filling material and the root canal walls (12). These gaps can allow leakage of bacteria or their components and byproducts into the dentinal tubules and periapical tissues $(1,12)$. Furthermore, it has been observed that plastic filling materials and sealers penetrate better into dentinal tubules after smear layer removal (13). It may be assumed that such penetration can increase the interface between the filling and the dentin, which may improve the material's ability to prevent further leakage (1). Peters and Harrison (2), using a dye leakage model, reported that citric acid demineralization of resected root surfaces had no significant effect on the sealing ability of amalgam, IRM or gutta-percha retrofils in comparison to similar undermineralized groups.

In the present study, the root-end cavities and resected apical surface were either not treated (group 1) or treated (groups 2, 3 and 4) with demineralizing agents for smear layer removal prior to Pro Root MTA retrofilling. Wu et al. (8), in a previous study using fluid transport model, did not remove the smear layer from the root sections before obturation with MTA.

Dye penetration is often used for leakage studies because dyes are relatively easy to be stored, applied and to have their penetration assessed quantitatively $(1,14)$. Moreover, if a filling material does not allow penetration of small molecules such as dyes, it is likely that it has potential to prevent leakage of larger molecules, such as bacteria and their byproducts (5). Several types of dyes, i.e., methylene blue $(6,10,14)$, fuchsine (15), India ink $(12,14)$ and rhodamine $(5,10)$ have been used. In a pilot study, $2 \%$ rhodamine B solution was 
prepared by dissolving rhodamine $\mathrm{B}$ crystals in distilled water and the resulting dye was found to be acidic $(\mathrm{pH}$ 1.8). Starkey et al. (16), while evaluating the effect of $2 \%$ methylene blue dye at different pHs $(1,1.96,2.66$, 2.73, 4.84 and 6.78) on apical leakage, observed dissolution of the exposed root apices in the groups at $\mathrm{pH} 5.0$ or lower. Therefore, in the present study, 2\% rhodamine $B$ aqueous solution at $\mathrm{pH} 7.03$ in a phosphate buffer was prepared by mixing $2 \mathrm{~g}$ of rhodamine B powder with $100 \mathrm{~mL}$ of $0.2 \mathrm{M}$ phosphate buffer solution at $\mathrm{pH}$ 7.0.

The mean extension of dye penetration at tooth/ material interface in group 1 was $1.89 \mathrm{~mm}$. This result is not in agreement with the findings of previous studies $(5,6,9)$. On the other hand, it is consistent with the results of Zanetti et al. (17), who also used rhodamine $\mathrm{B}$ and observed mean leakage of $1.10 \mathrm{~mm}$.

Gilheany et al. (18) reported that the permeability of the resected apical dentin and microleakage around the retrograde filling material had a significant influence on apical leakage. Torabinejad et al. (5) reduced the amount of rhodamine B dye penetration through the exposed dentinal tubules by sealing the resected surface with a layer of adhesive. Moreover, it has been shown that, in the fluid-conductive device, the fluid movement could take place in the MTA retrofil because it is a hydrophilic aggregate material that requires moisture for its setting reaction (19). In this study, the exposed dentinal tubules of apical root resections were not sealed with an adhesive layer and dye were prepared in aqueous solution. This may partly explain why the dye could penetrate at least 6 -fold deeper over the full length of the root-end cavities in eight of the tested specimens.

In their studies, Torabinejad et al. (6) and Aqrabawi (9) used 72-h immersion in 1\% methylene blue dye to penetrate MTA root-end fillings. These authors observed mean dye penetration of only $0.28-0.31 \mathrm{~mm}$ and no leakage, respectively. Wu et al. (20) reported that $1 \%$ methylene blue dye solution may be discolored by some dental filling materials (amalgam, calcium hydroxide, zinc oxide eugenol cement, Cavit and MTA), which may result in unreliable results for these materials in dye leakage studies. This was one of the reasons why $2 \%$ rhodamine $\mathrm{B}$ aqueous solution was the dye of choice in of $\mathrm{pH} 7.03$ in a phosphate buffer for $24 \mathrm{~h}$.

Wu et al. (8) reported that the seal produced by MTA leaked after $24 \mathrm{~h}$. However, MTA sealing was greatly improved during the first 3 months and was maintained until the end of the experiment (8). This may probably be attributed to further hydration of MTA powder by moisture, which can result in an increase in compressive strength and decrease in leakage. In the present study, MTA sealing was assessed $24 \mathrm{~h}$ after retrofilling. This may possibly explain why dye penetration means ranged from 1.89 to $2.64 \mathrm{~mm}$ after 24-h immersion in dye solution.

In a previous study (2), a demineralizing agent ( $1 \%$ citric acid, $\mathrm{pH} 1$ ) was applied only on apical section surface, after insertion of the retrofilling material. It was observed that the use of demineralizing agents did not affect retrofil sealing. Accordingly, in this study, groups $1,2$ and 4 had statistically similar results ( $>>0.05)$.

Group 3 (17\% EDTA solution, $\mathrm{pH}$ 7.0, for 3 min) had dye leakage means statistically similar ( $>>0.05)$ to those of groups 2 (35\% phosphoric acid, for $15 \mathrm{~s}$ ) and 4 (24\% EDTA gel, pH 7.0, for $4 \mathrm{~min})$. These findings confirm the hypothesis that the demineralizing agents possibly produce changes in dentin surface permeability (1).

Gagliani et al. (15) reported that the extension of leakage on marginal interface of apical retrofils (Super Seal), assessed with $0.5 \%$ fuchsin after application of 17\% EDTA buffered solution pH 7.5 on the sectioned surface, was never greater than $2.4 \mathrm{~mm}$. However, in the present study, the application of 17\% EDTA solution at pH 7.0 for 3 min (group 3) and 24\% EDTA gel at pH 7.0 for $4 \mathrm{~min}$ (group 4 ) on root-end cavities and resected apical surface yielded greater leakage of $2 \%$ rhodamine B (2.64 mm and $2.54 \mathrm{~mm}$, respectively).

Dye marginal leakage in group 3 produced significantly higher leakage means than the group in which no demineralizing agent was used (group 1). In group 4, however, four specimens showed leakage $>3$ $\mathrm{mm}$ and other two specimens had $2.95 \mathrm{~mm}$, while in group 3 only two specimens showed leakage $>3 \mathrm{~mm}$. A possible explanation could be the small sample size, composed by fourteen specimens in each group.

Several studies using different methodologies have been carried out to assess the marginal sealing of the MTA and have shown its effectiveness in preventing or reducing leakage, as well as its good adaptation and less amount of marginal cracks $(5-9,17)$. However, in this investigation, MTA retrofils showed dye leakage means from 1.89 to $2.64 \mathrm{~mm}$.

Based on the data presented herein, it is not possible to state which demineralizing agent should be 
used in periradicular surgeries with Pro Root MTA retrofils because other factors (i.e., biocompatibility and effect of the agent on the biological properties of MTA) may influence its clinical performance. No significant differences in retrofilling leakage with Pro Root MTA were observed when 35\% phosphoric acid and 24\% EDTA gel were used.

\section{RESUMO}

O objetivo deste estudo foi avaliar o selamento de ápices radiculares tratados com diferentes agentes desmineralizantes e retrobturados com agregado de trióxido mineral (MTA), mediante infiltração marginal por corante. Cinqüenta e seis dentes unirradiculares humanos extraídos foram instrumentados, obturados e seccionados apicalmente. Os preparos cavitários apicais foram confeccionados com pontas ultra-sônicas e os agentes desmineralizantes foram aplicados previamente à retrobturação com Pro Root MTA. Os espécimes foram divididos aleatoriamente em 4 grupos (n=14): grupo 1 (sem agente desmineralizante); grupo 2 (ácido fosfórico 35\% durante 15 s); grupo 3 (solução de EDTA 17\%, pH 7, durante 3 min); grupo 4 (gel de EDTA 24\%, pH 7, durante $4 \mathrm{~min}$ ). A extensão da infiltração de corante (rodamina B $2 \%$ a $37^{\circ} \mathrm{C}$, por $24 \mathrm{~h}$ ) foi avaliada em milímetros utilizando-se um estereomicroscópio. Os resultados foram analisados estatisticamente por meio de análise de variância a um critério e do teste Tukey com nível de significância de 5\%. Dentre os grupos experimentais, a menor extensão de infiltração do corante foi verificada no grupo $1(1,89 \mathrm{~mm})$, seguido pelos grupos 2 (2,18 mm), 4 (2,54 mm) e 3 (2,64 mm). Não houve diferenças estatisticamente significante $(\mathrm{p}>0.05)$ na infiltração marginal pelo corante entre os grupos 1 , 2 e 4 e os grupos 2, 3 e 4 . Com base nos resultados obtidos, pode-se concluir que a aplicação de agentes desmineralizantes não pode ser recomendada quando da utilização do MTA em cirurgias parendodônticas.

\section{ACKNOWLEDGEMENTS}

The authors would like to thank Gnatus Equipamentos MédicoOdontológicos for supplying the Ultasonic tips (S12D-90 model); Dr. Clóvis Pagani for helpful technical assistance; Dr. Marco A. Leonel Caetano and Ivan Balducci (Department of biostatistics, Faculty of Dentistry of São José Campos) for assistance in statistical analysis; and Dr. Cristiane Y. Koga Ito (Department of Bioscience and Oral Diagnosis, Faculty of Dentistry of São José Campos) for assistance in manuscritpt preparation.

\section{REFERENCES}

1. Sen BH, Wesselink PR, Türkün M. The smear layer: a phenomenon in root canal therapy. Int Endod J 1995;28:141148.

2. Peters LB, Harrison JW. A comparison of leakage of filling materials in demineralized and non-demineralized resected root ends under vacuum and non-vacuum conditions. Int Endod J 1992;25:273-278.
3. Torabinejad M, Chivian N. Clinical applications of mineral trioxide aggregate. J Endod 1999;25:197-205.

4. Holland R, Souza V, Nery MJ, Otoboni Filho JA, Bernabé PFE, Dezan Junior E. Reaction of rat connective tissue to implanted dentin tubes filled with mineral trioxide aggregate or calcium hydroxide. J Endod 1999;25:161-166.

5. Torabinejad M, Watson TF, Pitt Ford TR. Sealing ability of a mineral trioxide aggregate when used as a root end filling material. J Endod 1993;19:591-595.

6. Torabinejad M, Higa RK, McKendry JD, Pitt Ford TR. Dye leakage of four root-end filling materials: effects of blood contamination. J Endod 1994;20:159-163.

7. Torabinejad M, Smith PW, Kettering JD, Pitt Ford TR. Comparative investigation of marginal adaptation of mineral trioxide aggregate and other commonly used root-end filling materials. J Endod 1995;21:295-299.

8. Wu MK, Kontakiotis EG, Wesselink PR. Long-term seal provided by some root-end filling materials. J Endod 1998;24:557-560.

9. Aqrabawi J. Sealing of amalgam, super EBA cement and MTA when used as retrograde filling materials. Br Dent $\mathrm{J}$ 2000;188:266-268.

10. Delfin LE, Carvalho RG, Ferreira M, Fidel R, Fidel S, Moreira E. Avaliação da capacidade seladora de alguns materiais usados nas retrobturações. Pesqui Odontol Bras 2000;14:60 (Abstract I386).

11 Holland R, Okabe JN, Holland Junior C, Souza V, Mello W, Saliba O. Influência do emprego do vácuo na profundidade da infiltração marginal do azul de metileno em dentes com canais obturados. Rev Assoc Paul Cir Dent 1990;44:213-216.

12. Barthel CR, Moshonov J, Shuping G, Orstavik D. Bacterial leakage versus dye leakage in obturated root canals. Int Endod J 1999;32:370-375.

13. White RR, Goldman M, Lin PS. The influence of the smeared layer upon dentinal tubule penetration by plastic filling materials. J Endod 1984;10:558-562.

14. Youngson CC, Glyn Jones JC, Manogue M, Smith IS. In vitro dentinal penetration by tracers used in microleakage studies. Int Endod J 1998;31:90-99.

15. Gagliani M, Taschieri S, Molinari R. Ultrasoni root-end preparation: influence of cutting angle on the apical seal. J Endod 1998;24:726-730.

16 Starkey DL, Anderson RW, Pashley DH. An evaluation of the effect of methylene blue dye $\mathrm{pH}$ on apical leakage. J Endod 1993;19:435-439.

17. Zanetti R, de Deus G, Coutinho T, Gurgel E, Maniglia C, Krebs R, Pinto T. Estudo da performance do MTA como material retrobturador. Pesqui Odontol Bras 2000;14:44. (Abstract I258).

18. Gilheany PA, Figdor D, Tyas MJ. Apical dentin permeability and microleakage associated with root end resection and retrograde filling. J Endod 1994;20:22-26.

19. Yatsushiro JD, Baumgartner JC, Tinkle JS. Longitudinal study of the microleakage of two root-end filling materials using a fluid conductive system. J Endod 1998;24:716-719.

20. Wu MK, Kontakiotis EG, Wesselink PR. Decoloration of $1 \%$ methylene blue solution in contact with dental filling materials. J Dent 1998;26:585-589.

Accepted August 28, 2003 